\title{
Quality of tender documents: case studies from the UK
}

Article

Accepted Version

Laryea, S. (2011) Quality of tender documents: case studies from the UK. Construction Management and Economics, 29 (3). pp. 275-286. ISSN 0144-6193 doi:

https://doi.org/10.1080/01446193.2010.540019 Available at https://centaur.reading.ac.uk/16296/

It is advisable to refer to the publisher's version if you intend to cite from the work. See Guidance on citing.

To link to this article DOI: http://dx.doi.org/10.1080/01446193.2010.540019

Publisher: Taylor \& Francis

All outputs in CentAUR are protected by Intellectual Property Rights law, including copyright law. Copyright and IPR is retained by the creators or other copyright holders. Terms and conditions for use of this material are defined in the End User Agreement.

\section{www.reading.ac.uk/centaur}

\section{CentAUR}

Central Archive at the University of Reading

Reading's research outputs online 


\title{
Quality of tender documents: case studies from the UK
}

Samuel Laryea

School of Construction Management and Engineering, University of Reading, UK, RG6 6AW

\begin{abstract}
Tendering is one of the stages in construction procurement that requires extensive information and documents exchange. However, tender documents are not always clear in practice. The aim of this study was to ascertain the clarity and adequacy of tender documents used in practice. Access was negotiated into two UK construction firms and the whole tender process for two projects was shadowed for 6-7 weeks in each firm using an ethnographic approach. A significant amount of tender queries, amendments and addenda were recorded. This showed that quality of tender documentation is still a problem in construction despite the existence of standards like Coordinated Project Information (1987) and British Standard 1192 (1984 and 1990) that are meant to help in producing clear and consistent project information. Poor quality tender documents are a source of inaccurate estimates, claims and disputes on contracts. Six recommendations are presented to help in improving the quality of tender documentation. Further research is needed into the recommendations to help improve the quality of tender documents, perhaps in conjunction with an industry-wide investigation into the level of incorporation of CPI principles in practice.
\end{abstract}

Keywords: case study, contractor, tender documentation, tendering, UK 


\section{Introduction}

Tendering is one of the stages in a construction project that requires extensive information and documents exchange. Clients typically provide contractors with a set of tender documents for a bid proposal upon which a contract may be let and executed (as explained in a standard textbook on construction contracts by Murdoch and Hughes, 2008). Such tender documents often contain the information about a client's project plans so that a contractor can price it. However, in practice, tender documents are not always clear, consistent and adequate. This makes the calculation of a tender programme and price for a construction project difficult. Several aspects of the literature in construction management indicate that the quality of tender documents is often "poor" in practice (see for example, studies by Liu and Ling, 2005; Fang et al., 2002; Akintoye and Fitzgerald, 2000 and Smith and Bohn, 1999). However, there is little empirical research in the literature on the quality of tender documents used in construction and the practical implications of poor quality tender documents in construction. Therefore, the aim of this study was to examine and analyse the clarity and adequacy of tender documentation in practice. To be able to do this, it was important to capture the reality of the problem. Therefore, access was negotiated into the offices of two of the top 20 UK civil engineering construction firms (Hansford, 2008) and the whole tender process was shadowed, for six and seven weeks respectively, to gain a first hand understanding of the quality and nature of tender documents.

\section{Theoretical framework}

\section{Construction tendering}

Tendering is the process used by many construction clients to obtain the programme and price for building a project (Brook, 2004). It typically consists of three parts: deciding on the type of contract and the terms and conditions that would form the basis of the contractual relationship and under which the work will be done; selecting the most suitable contractor given the budget and time available; and establishing the contract price (Hackett et al., 2007). These issues are further explained in a construction contracts textbook by Murdoch and Hughes (2008). 


\section{Tender documents}

The tender documents of a project should typically contain the design and specification of what the client wants to build. It is the same documentation that a contractor (bidders) needs to calculate and offer a price and programme for a project. An experiential-based textbook on estimating and tendering in construction by Smith (1986: 33) defines "tender documents" as "all the relevant information about the proposed contract, rules, conditions, etc. supplied to the contractor which will enable him to price the work as accurately as possible, taking into account all the special peculiarities which every building project possesses". An experiential-based textbook on theory and practice of construction tendering by Cook (1991: 76) explains that the purpose of tender documents are "to provide each builder with common data in sufficient detail to suit the circumstances of a project". Tender documents also help to obtain competitive tenders that can be evaluated objectively to select a suitable contractor.

Tender documents typically comprise documents such as bill of quantities/schedule of rates, drawings, instructions to tenderers, specifications, form of contract, conditions of contract and a list of enclosures (Bentley, 1987: 10; Smith, 1986: 34; Cook; 1991: 76; Buchan et al., 2003). Standard textbooks on construction tendering and estimating for example, Bentley (1987: 10) and Cook (1991: 76) explain that the tender documents given will depend on factors such as the contractual arrangement (i.e. lump sum contract, measurement contract or cost reimbursement), procurement method and size of the project (i.e. major or minor contract works). For example, both Smith (1986: 27,33) and Bentley (1987: 10) explain that the tender documents for contract works of a minor nature contract may comprise of drawings with or without specifications.

\section{Quality of tender documents}

Poor specification writing, disparities between bill of quantities and drawings and specifications, and poorly prepared tender documents are common problems associated with tender documents in the UK according to Brook (2004: 46). Problems associated with technical information prepared by designers led to the appointment of a Co-ordinating Committee for Project Information (CCPI) in 1979. The CCPI report (1987) indicated that major problems associated with quality of information in drawings, specifications and bills of quantities included missing 
information, late information, wrong information, insufficient detail, impracticable designs, inappropriate information, unclear information, provisional information, poorly arranged information, uncoordinated information and conflicting information.

Following further work within the industry, the CCPI published three Codes of Procedure for Production Drawings, Project Specifications and the Common Arrangement of Work Sections for Building Works in 1987. These codes encourage designers and design teams to follow the principles of CPI as an aid to efficient project delivery. Prior to the introduction of CPI, a Building Economic Development Council (1987) NEDO report had indicated that nearly 30\% of quality problems on building sites were mainly due to unclear or missing project information.

\section{Consequences of poor tender documents}

Poor quality tender documents can lead to inaccurate estimates, higher margins in bids, claims and disputes. A questionnaire survey of 84 UK contactors identified "poor tender documents" as the second major cause of inaccurate cost estimates. Most respondents revealed that "...the quality of tender information provided by design teams is poor" (Akintoye and Fitzgerald, 2000: 170). Liu and Ling (2005: 394) identified "completeness of tender documents" as a significant factor affecting markup in a questionnaire study of 29 US contractors. Shash (1998: 104) also identified "clearness of work's specifications" as one of the factors influencing a contractor's markup decision. An interview study of 30 US contractors by Neufville and King (1991) found that "quality of design" is one of the factors frequently associated with level of markup.

Based on interviews with 12 US contractors, Smith and Bohn (1999: 106) found that "unclear contract documents" was one of the factors that cause contractors to increase contingency markups in bids. A questionnaire study of 19 contractors in Australia by Bajaj et al. (1999) identified "quality of tender documentation" as the third most significant factor influencing a contractor's decision to bid for a job. Another questionnaire survey of 32 contractors in Singapore by Dulaimi and Hong (2002: 606) found that out of 40 factors influencing bid/no-bid decision of contractors in Singapore, "completeness of tender documents" was the eighth most important. Fang et al.'s (2002: 857) questionnaire study of 42 contractors in China identified "errors in working drawings" as a significant risk factor for contractors operating in the Chinese construction market. Brook (2004: 46) explains that poor tender information can add to time 
wasted by site supervisors. Hence, the clearer the tender documentation, the more straightforward the construction process will be and the lesser the cost of tendering will be to a contractor. The time spent by estimators writing assumptions, specifications and doing guesswork clearly adds to the costs of tendering (Smith, 1986).

\section{Research questions}

The literature shows that quality of tender documentation is a problem in construction. However, there is little empirical research on the extent to which tender documents are unclear in practice, the nature and implications of poor quality documents, areas where the problems with tender documents are concentrated and how contractors deal with poor quality tender documents. Without a precise understanding of the quality of tender documents in practice, it would be hard to achieve the improvements anticipated with the introduction of CPI and British Standards on project information. Therefore, the following questions should be addressed:

(1) What kinds of tender documents are given in practice?

(2) What is the nature of tender documents in terms of structure and size?

(3) What problems do contractors often encounter in the use of tender documents?

(4) What aspects of tender documents are often unclear to contractors?

(5) What are the main causes of unclear tender documents?

(6) How do contractors respond to unclear aspects of tender documents?

(7) What are the consequences of poor quality tender documents in practice?

\section{Research method}

To address the research questions, a comprehensive, inductive and intensive method was required (as explained in Mintzberg, 1973: 230 in his live observational study of five US managers in 1967-69). In the first instance, a comprehensive method was required for capturing the whole tender process of contractors, tender documents and the issues associated with them. Second, the method had to be inductive in that the aim was to develop theory inductively and provide an understanding on the quality and nature of tender documents based on specific cases. Third, the method had to be intensive to help probe deeply into the research questions. Therefore, access was negotiated into two of the top $20 \mathrm{UK}$ construction firms (Hansford, 2008) using a 
written request in the first instance and then face-to-face discussions. Both contractors (with an annual turnover of more than $£ 1 b n)$ execute building and civil engineering projects.

In each of the firms, hereafter referred to as Gamma and Delta, the whole tender process was shadowed for six weeks in Gamma and seven in Delta both in 2008. Thus, the entire study lasted for 65 days i.e. 552.5 hours of direct observation as the working hours was 0800-1730 (with onehour of break time each day). To obtain a comprehensive understanding of documents involved in the tender process, the bid teams were assisted by the researcher in their daily work. Questions were asked to clarify the researcher's observations and to also learn about general experiences. Tender documents were collected, examined and analysed. Thus, three main methods were used in this ethnographic research i.e. observation, interview and documentary analysis. There were about ten people in the bid team in each firm with the main personnel being a bid manager, estimator, planner, commercial manager, business manager and administrative assistant. The observations, unstructured interviews and documentary analyses carried out over a period of six weeks in Gamma and seven in Delta formed the basis of the case studies reported. Case studies are often limited in their capacity to be representative of a whole population (Yin, 2003). Therefore, although the research was conducted in two of the top $20 \mathrm{UK}$ construction firms that have a major presence across the UK and a wide range of experience when it comes to tender documents, the results may not be generalized for the entire UK construction industry.

Perception, reflexivity and presence of the researcher are common problems associated with ethnographic research of such nature (Silverman, 1997; Gill and Johnson, 2002; Denscombe, 2008). Here, however, the research interest was in tender documentation and much of the detail was uncontroversial, with little need for sophisticated interpretation of documents given, problems associated with the documents and written queries relating to the problems. Also, tendering is a commercially expensive exercise where procedures are not likely to be influenced by the presence of a researcher. Hence, the results are not likely to be influenced much by these three factors. The bid teams were comfortable with the presence of the researcher and appreciated the extra pair of hands provided by the researcher for some routine tasks, and were keen to receive a feedback report which was promised in return for access to the case studies. 


\section{Case studies}

The case studies conducted in Gamma and Delta in 2008 are now examined and analysed.

\section{Analysis: Case Study 1 (Gamma)}

The tender documents in Gamma related to an "enabling works" project valued at $£ 6.5 \mathrm{~m}$. The project was for a public client and the conditions of contract used was ICE $7^{\text {th }}$ Edition. The project was awarded as a Guaranteed Maximum Fixed Price contract.

The tender documents received comprised of instructions to tenderers (seven volumes), form of tender, form of agreement, form of bond, conditions of contract, special requirements, information to be supplied by the tenderer, information supplied to the tenderer, collateral warranty by contractor, collateral warranty by subcontractor, collateral warranty by designer, parent company guarantee, technical work specifications (358 pages), project drawings (213 pages) and bill of quantities (1053 bill items).

In terms of problems encountered with tender documents, first, the bid team in Gamma identified areas in the documentation where there were missing information, incomplete drawings, conflicting information, inadequate specifications (see Table 1) and general areas requiring clarification of information. In relation to these problems, the bid team in Gamma raised 20 tender queries (TQs) that they submitted to the client's consultants for additional information. Table 1 shows the analysis of the 20 TQs raised by Gamma.

\section{<TABLE 1> NEAR HERE}

The number of TQs raised by Gamma could have been more than 20 but the bid team members were strategically reluctant about raising too many queries. First, they expressed concerned that too many TQs might be misinterpreted by the consultants to mean that they did not understand the job. Second, they thought that raising too many TQs could divulge commercially advantageous information. For example, if a section of the drawings or specifications was flawed and there was a possibility for claims (and profit) in the construction phase, they would want to exploit rather than raise a TQ about it. Thus, some of the pricing and tender strategy was formulated to exploit flaws and lack of specific construction details in the tender documentation. 
Second, a significant amount of changes to the original tender documents were introduced by the client during the six-week tender process. The changes were mainly issued through TQs and TAs issued to supplement the information originally given. Table 2 examines and categorises the TAs received. Interestingly, TA1 was received on the first day of the tender period to correct an error relating to date of tender submission.

\section{$<$ TABLE 2> NEAR HERE}

Table 3 categorises the 90 TQ responses that were received. The total number of TQs raised by Gamma was 20. However, there were three other bidding contractors and they also raised queries about the tender documents. Ultimately, 90 TQ responses were received by Gamma so it is assumed that altogether the project consultants received a minimum of 90 TQs.

\section{$<$ TABLE 3> NEAR HERE}

Each TQ response was circulated to all contractors. This meant that the consultants did not have to answer a TQ on the same subject more than once and it also ensured that all contractors were tendering on the same information. Thus, nearly no TQ response was a duplicate of other bidders' queries. Table 4 shows the weekly distribution of TQ responses received by Gamma.

\section{$<$ TABLE 4> NEAR HERE}

$53 \%$ of TQ responses were received in the final two weeks of the six-week tender period. The bid team in Gamma expressed serious concern about this because many of the TQ responses had significant consequences for the tender programme and price. With the limited time available, it was difficult for Gamma to take proper account of the changes in the tender submission. Some of the queries were not answered (see Table 4) and in some cases the TQ response was not considered to contain adequate information. In relation to these issues, the bid team based the tender programme and price on written assumptions accompanying the bid submission.

Other tenderers also expressed concern about the delay in providing information needed to price the work well. For example, one contractor wrote in a TQ to the consultants, ahead of a tender clarification meeting, as follows: "With the tender clarification meeting next week, we are concerned that discussions and information gained will leave limited time to process before 
tender return date. It is obviously too late now, but an introductory meeting to all tenderers would have been very beneficial on a project of this nature".

There was a provision in the ITT which required contractors to raise all TQs at least two weeks prior to tender submission date. From the original tender submission date of $08 / 08 / 2008$, the deadline for raising queries was calculated to be 25/07/2008. Nonetheless, the tender clarification meeting with the client and project consultants took place on 24/07/2008. In theory, this meant that tenderers had just one day to raise TQs arising out of the meeting discussions. There were still many issues and unsupplied information at this stage. The consultants issued Gamma with two CDs (containing additional drawings and specifications) at the clarification meeting and promised to supply more information. To compensate for the new information (drawings and specifications) given, the tender period was extended by one week. Table 2 shows that $90 \%$ of the tender addenda (TAs) were issued in the final two weeks of the tender period. The last TA was received practically two days before the tender submission date. Contractors had little time to take account of the changes and new information. And this was interesting because the client had indicated in the ITT that they wanted a tender that was "free from qualifications". In the end, Gamma submitted a bid that was "qualified" because of issues that still needed to be clarified with the client before they could agree a GMFP for the project. Hence, the main problems encountered with the tender documentation were insufficient information, amendments to the original documents through TQs and TAs, late supply of information and late response to TQs.

On aspects of the tender documents where problems are concentrated, an examination of Table 5 which details the 20 TQs raised by Gamma shows the main areas as instructions to tenderers (9), specifications (8), missing/unsupplied information (2), drawings (2) and inconsistent information between specification and drawings (1).

\section{$<$ TABLE 5> NEAR HERE}

The analysis here does not include clarity of conditions of contract. In relation to this, a "commercial review" was done to provide an appropriate commercial response. The estimator explained that the conditions of contract are more about risk, liabilities, obligations and payment terms. The conditions of contract may not affect the rates and price offered but it tends to have an impact on the final tender submission in terms of the risk approach taken to the scheme. 
On the main causes of unclear tender documents, this question was investigated in interviews with members of the Gamma bid team. The interviews revealed cases where 100+ TQs and 30+ TAs had been experienced in relation to the tender documents of a single project. The estimator said that as high as 417 TQ responses had been experienced in one case and he criticized the quality of tender documents: "The quality of tender documents nowadays is very bad. It has plummeted over the past 10 years. Clients don't want to invest. You get what you pay for. In the past, clients would take up to four years to prepare their documents, and there would be just one or two changes. But nowadays, clients spend just about six months and want a price in just 4-6 weeks. Because of time pressure, we get bad tender documents which results in sometimes 100s of queries and sometimes dozens of amendments. In some cases, we have had 30 amendments and to me that is a client who does not know what he is doing. Nobody wants to work for a client like that. In the past, tender documents used to be very detailed and well organised".

"Nowadays, you get a mismatch of documents with no proper order and structure. Most documents received nowadays are not to the standard and clarity needed to give an unqualified, good and competitive offer. In fact, our expectation of the [tender documents] we are going to get [from clients] is very low nowadays. A majority of tender documents are hardly good; a significant minority are good but also a significant minority are appalling". "Nowadays most tender documents are in electronic format. You get the tender documents for most large schemes on DVD. Sometimes the tender documents are on six full DVDs and you have to price everything in a maximum of 12 weeks. Sometimes, you would have to log on to a client's portal and download the tender documents. After pricing it, you log on again and upload your whole submission - e portal submission. For example, this applies to the Olympics project and for most Local Councils. The client will give you a PIN number and a password in the 'Invitation to tender' then you go onto their website and get the documents. Navigating around the website itself is a lot of problem for us as a lot of the information is difficult to find and not well structured and organised". Thus, the main causes of unclear documents relate to time and money. In relation to the problems associated with tender documents, the observations, interviews and documentary analysis indicated that contractors respond with written assumptions, qualifying their bid and raising queries in the tender process to request for more information. 


\section{Analysis: Case Study 2 (Delta)}

The tender documents in Delta relate to infrastructure works proposed to expand and enhance a railway terminal. The project was for a public client. It was valued at $£ 7.5 \mathrm{~m}$ and comprised of platform works, a footbridge, track works, overhead line equipment works, and signalling works. The work was to be awarded as a fixed price contract.

The "Invitation to tender" indicated that the tender documents comprised of instructions to tenderers, contractual arrangements, contractual requirements and tender submission documents. The tender documents in Delta was issued in the form of 33 Appendices (1039 pages) plus a Technical Works Scope (51 pages) i.e. 1090 pages in total. This was grouped in two sections. Section 1: instruction to tenderers; contract arrangements (terms and conditions, conditions of contract appendix, contract specific conditions, claims allocation and handling management); contract requirements (technical workscope, preliminaries, HSQE, key personnel). Section 2: tender submission documents (form of tender, compliance statements, tenderer's assumptions, contract breakdown and supporting tender information). Table 6 summarizes the tender query (TQ) and emails sent by Delta to request for more information from the client.

\section{<TABLE 6> NEAR HERE}

There was a template provided by the client for writing TQs. The TQ template stated that "The tender queries shall be circulated to all tenderers. The tenderer may identify any query as 'commercially sensitive' in which case the client reserves the right not to answer the query, but shall treat the matter as confidential whether or not a response is issued". Thus, a TQ marked 'commercially sensitive' was not circulated to other tenderers. The bid team in Delta explained that they would mark a TQ as 'commercially sensitive' if they thought it could divulge information about their construction or bid-pricing methodology. The TQ shown in Table 6 was marked 'commercially sensitive' and it received no response from the consultants.

\section{$<$ TABLE 7> NEAR HERE}

One reason for the low number of TQs raised by Delta may be due to the strategy for dealing with TQs and quality of the client's documents. The Technical Services Director explained that 
"In dealing with the quality of the client's documents, you should always try to be as proactive as you can in picking up the issues. You should always be looking at what the advantage will be. I don't normally like to put a lot of TQs in. If there is a genuine TQ, I put it in. However, I rationalize it and think about it more. If there is some commercial advantage in it, I don't query. [In practice], the client allows you to make assumptions, regardless of what they tell you in the tender. The flip side [and the consideration you have to make] is what your competitors are going to do. If there is no commercial advantage in it, it is a leveller for everyone. However, the approach we are happy to take as a company is that we don't ask TQs about the way we are going to do the work. We should have sufficient experience within our business which we shouldn't be asking the client too many questions. It is better for us to state in our bid the assumptions upon which our bid/offer is based than to be asking too many queries". One member of the bid team disagreed with the TQ approach described and argued that "Part of winning the job is how you engage the client in the tender process. If you put a couple of TQs in, it implies that you are thinking about the job. On the other hand, issuing many TQs could lead to sending out a lot of commercially sensitive information that gives advantage to your competitors. Hence, there is a balancing act to do with respect to generating TQs".

\section{$<$ TABLE 8> NEAR HERE}

Delta received a total of 23 TQ responses from the project consultants (see Table 7) meaning that the other bidders also raised TQs. Table 7 examines and analyses the TQ responses. The main problems experienced by contractors related mainly to insufficient information in the documents provided, unsupplied documents, errors and mistakes in the documents. Some of the TQ responses were not considered adequate. There are also areas of the documents that were not queried because of commercial sensitiveness. In relation to these issues, the bid team based the tender programme and price on written assumptions that accompanied the submission.

Table 8 shows that $87 \%$ of TQ responses were received in week four of the seven-week tender period. This was due mainly to nature of the consultant's administrative procedures. The consultants preferred to collate a number of TQs and then respond to them simultaneously. Table 9 shows the additional information and amendments introduced during the tender process.

\section{<TABLE 9> NEAR HERE}


In Delta, the meeting observations and interviews with members of the bid team revealed major concerns about the nature of tender documents nowadays and also causes of poor documents. In a meeting, a Technical Services Director said that "It is not our job to sort the design out. We will just price in a way that is to our best advantage." As the drawings were not complete, one member of the bid team said that "It is likely that there will be some changes to that particular aspect so it is potentially good for making money. It is a huge tender but with a lot of issues". In a letter to the client, Delta indicated that "We would need at least three/four weeks extension to the tender period because of the quality of the tender documents... we will end up qualifying our price with a lot of assumptions". The following statements were also recorded in relation to tender documents: "There is a conflict of information on completion - differently stated in Appendix and scope documents". "The client is not sure yet of power supply and many other things. That means some items will be re-priced afterwards and that is good for us commercially". "We have issues with regard to clarity and scope of what the client had given us". The estimator explained that "Risk is about information and method of doing the work. If contractors are clearer about things, there is little risk to the price". The bid manager said that in comparison to other industries, some features that make construction unique include the use of "outline drawings for contractors", "tight timescales for delivery", "design is very sketchy" and "the way that tender documents are put together is not very professional".

\section{Discussion}

Six main points are brought forward for discussion. First, the research reveals that the main tender documents given in practice are instructions to tenderers; conditions of contract; specifications; bill of quantities; drawings; and other information like site investigation report, planning permissions, possessions, etc. This aligns closely with the tender documentation literatures in Bentley (1987: 10); Smith (1986: 34); Cook (1991: 76); Buchan et al. (2003); Brook (2004) and the CIOB (2009) Code of Estimating Practice. The main difference found is in the way that different parts of the entire tender documentation is organised and arranged for contractors. Here, for example the tender documents in Gamma were issued in the form of seven Volumes whilst the documents in Delta were issued in the form of 33 Appendices and a Technical workscope. Hence, there appears to be no standard format to organising and arranging

tender documents. Although the documents issued may contain basically the same type of 
information such as drawings, specifications and conditions of contract, the format and structure in which it is issued may vary among clients and consultants. The chief estimator in Gamma explained that the three main documents needed to put a price together are drawings (what is it?); specifications (what is it made of?); and bill of quantities (how much of it is there?).

Second, the tender documents observed and examined in Gamma and Delta contained a significant amount of information that contractors were required to process into a single price and programme in 6-7 weeks. In Gamma, the tender documents for the $£ 6.5 \mathrm{~m}$ project comprised of 213 pages of drawings, 358 pages of specifications and 1053 items specified in the bill of quantities. This was in addition the standard Highway Agency Specifications that contractors were expected to know. In Delta, the tender documents for the $£ 7.5 \mathrm{~m}$ project were contained in 1090 pages of information spread across 33 Appendices comprising of drawings, specifications and conditions of contract. The literature in the CIOB (1997) Code of Estimating Practice and standard estimating and textbooks, for example Brook (2004); Buchan et al. (2003); Smith (1986) does not typically reveal the size of tender documents in such terms. However, the research work here reveals a massive amount of information needed to be processed into a price and programme in a short time. Another tender/project that was being priced in Gamma had $700+$ drawings and additional information that had to be processed into a single price in 8 weeks. The bid teams in both firms considered the extensive amount of information that needs to be processed as one of the challenges of the tender process which becomes even worse when the information is not clear. The Managing Estimator revealed a notion among contractors that "whoever wins a tender probably won because they left something out which ought to have been priced". "There is a huge amount of documents that need to be read. The way we cope is that there is a large team dealing with it. There are often missing things, incomplete pages and contradiction information in tender documents". The massive amount of information contractors need to process into a single tender programme and price in short periods of time requires contractors to formulate effective, faster and more economic ways of capturing the information, understanding the information and using the information to process a programme and price.

Third, in terms of problems encountered with tender documents, the following were identified: missing information, incomplete drawings, conflicting information, inadequate specifications, software difficulties and errors and mistakes. In relation to these problems, 90 TQ responses and 
nine TAs were received in Gamma. 23 TQ responses and two TAs were received in Delta. Most of these contained significant changes that were difficult to price in the short time available. The contract in Gamma was GMFP and the one in Delta was Fixed Price. Both committed the contractors to programme and price risk and so the need to clarify unclear areas of the documents is likely to have had an impact on number of TQs and TAs. The interviews with bid team members in Gamma and Delta revealed that quality of tender documents has slumped considerably in the past 15-20 years. 'Quality' of tender documents was described as 'clarity [and adequacy] of the information needed to price the works. In the ideal situation, there should be no tender queries and tender amendments'. The interviews revealed common problems associated with quality of tender documents such as disparity between information in drawings, specifications and bill of quantities; inadequate information in tender documents; un-updated information; and poor organisation or structure of documents. The analysis of TQ responses in Gamma and Delta revealed significant problems such as missing information, incomplete drawings, conflicting information, inadequate specifications, errors and mistakes and omissions.

The problems perennially associated with tender documentation were identified in the CCPI (1987) report as missing information, late information, wrong information, insufficient detail, inappropriate information, unclear information, poorly arranged information, uncoordinated information and conflicting information. A significant evidence of these problems was found in the 90 TQ responses in Gamma and 23 in Delta. Bid team members in both Gamma and Delta narrated past experiences where clients often provided clearer tender documents. They explained that the documents were often arranged in a logical sequence and the bill of quantities, specifications and drawings would be consistent and adequate. This was contrasted with the present situation where tender documents are often unstructured, have missing information and contradicting information and a lot of time is often required to understand what a client really wants. The estimator in Gamma said that "The amount of time we spend to figure out what it is they want, compared to giving it to them is disproportionate". The estimator in Delta said that "The quality of tender documents and indeed the management of the tender process by employer's agents over the last ten years has fallen dramatically, and seems to be continuing to fall". The estimator's assertion that tender documents were clearer in the past is open to question. An industry-wide investigation is recommended into the level of incorporation of CPI (1987) principles in practice. There is also a British Standard (BS 1192: Part 1: 1984 on 'Construction 
Drawing Practice' and BS 1192: Part 5: 1990) which aims at production of accurate, clear, economical and consistent drawings. These standards should be enforced in practice.

Fourth, most problems were concentrated in the instructions to tenderers, specifications, drawings and the project description itself (see Tables 1-9). Fifth, questions asked to probe for reasons underlying the problems revealed four main reasons: most tender documents received are rushed and put together in a hurry; reluctance of client to invest money in getting good quality documents; ignorance (client just does not know what to do); and incompetence. It has been explained in Smith (1986: 27) that quality of tender documents may be affected by the level of skill of the one who prepares them. The bid teams in both Gamma and Delta were of the view that clients will get compliant and better tenders when they provide drawings that are clear on the workscope, specifications that are clear, and clear instructions on what to submit in the tender. The case studies here involve public clients. Further studies will be required to establish whether the type of client may have an influence on the quality of documents. For example, where public funds are not involved and there is not much pressure to start a project, a private client may be willing to invest the money and time needed to obtain more detailed documents.

Sixth, in relation to how contractors respond to problems with tender documents, the study revealed five main ways were found. First: pulling out of the tender process if the quality of documents is too poor and likely to lead to pricing and contractual difficulties. Second: arranging clarification meetings with clients. Third: issuing written queries for more information. Fourth: including a significant amount of risk money in the bid. Fifth: qualifying the bid. To explain how this is done, the chief estimator in Gamma said "We have experienced people who know what to do to produce a price. As they go through the documents, they will sort out and use their experience to pick up anomalies and areas requiring commercial attention". Some clients, for example the Highways Agency, do not want qualified bids. In such cases, contractors often use tender queries and meetings to resolve the problems so that a compliant bid can be offered. Both contractors identified lack of clarity in tender documents as a major source of claims and disputes in the contract phase. The estimator in Delta explained that "Clearer and more precise tender documents at the tender stage coupled with the allowance of a sensible tender period will invariably lead to sensible tenders and lower risk of dispute as a result of the client making clear what they want". The research participants made six recommendations that clients can adopt to 
improve quality of tender documents: know what you want; describe it very clearly; do not assume that the other person knows what you want, tell them what you want; do not change your mind; allow a sensible tender period; and be sensible about risk sharing.

\section{Conclusion}

The aim of the study was to ascertain the extent of clarity and adequacy of tender documents given in practice. This was done using an ethnographic approach where the whole tender process for two projects was shadowed in two leading UK construction firms. The main conclusions are that first, the type of tender documents used in practice align closely with the literature; however the format and structure vary considerably. Second, the volume of information provided was too extensive to allow tenderers to process and estimate a price and programme for the works in a short time. Third, the quality of tender documents is perceived to have dropped markedly in the past 15-20 years and this causes extensive problems for tenderers. Fourth, four main reasons for the decrease in quality of tender documents were identified i.e. client impatience, reluctance to invest more in good quality documents, ignorance and incompetence. Fifth, contractors respond to unclear tender documents in five main ways i.e. queries, assumptions, clarifications, qualifications and not bidding at all. Sixth, lack of clarity in tender documents was identified as a major source of claims and disputes at the construction stage. The significant amount of tender query responses and amendments indicates a gap between the theory behind CPI and what actually happens in practice in relation to quality of information provided by design teams. The study participants made six recommendations that clients can adopt to improve quality of tender documents: know what you want; describe it very clearly; do not assume that the other person knows what you want, tell them what you want; do not change your mind; allow a sensible tender period; and be sensible about risk sharing. The findings here are based on two ethnographic case studies. Further studies will be needed to develop the findings and formulate practical ways of adopting the six-point recommendation strategy.

\section{Acknowledgement}

The comments from four anonymous reviewers were very constructive and they have helped to improve this paper. 


\section{References}

Akintoye, A. and Fitzgerald, E. (2000) A survey of current cost estimating practices, Construction Management and Economics, 18(2), 161-72.

Bajaj, D., Oluwoye, J. and Lenard, D. (1997) An analysis of contractors' approaches to risk identification in New South Wales, Australia, Construction Management and Economics, 15, 363-369.

Bentley, J.I.W. (1987) Construction tendering and estimating, London: E. \& F. N. Spon

Brook, M. (2004) Estimating and tendering for construction work, 3ed, Boston: Butterworth Heinemann

Buchan, R.D., Fleming, F.W.E and Grant, F.E.K (2003) Estimating for builders and surveyors, 2ed, Oxford: Butterworth-Heinemann

Chartered Institute of Building (CIOB) (2009) Code of Estimating Practice, 7 Edition, WileyBlackwell, ISBN: 978-1-4051-2971-8

British Standards Institute (1984) Construction Drawing Practice: recommendations for general principles, BS 1192: 1984

Building Economic Development Council (1987) Achieving Quality on Building Sites, Report of the National Economic Development Office, London, U.K.

Cook, A.E. (1991) Construction tendering: theory and practice, London: B.T. Batsford Ltd

Department of the Environment (1976) Project information: its content and arrangement. Report of the Project Information Group

Dulaimi, M.F., Hong, G.S. (2002), The factors influencing bid mark-up decisions of large- and mediumsize contractors in Singapore, Construction Management \& Economics, Vol. 20 No.7, pp.601-10.

Buchan, R.D., Fleming, F.W.E and Grant, F.E.K (2003) Estimating for builders and surveyors, 2ed, Oxford: Butterworth-Heinemann

Fang, D., Fong, P. S. and Li, M. (2004) Risk assessment model of tendering for Chinese building projects, Journal of Construction Engineering and Management, 130(6), 862-868.

Hackett, M., Robinson, I. and Statam, G. (2007) Procurement, tendering, and contract administration, Oxford: Blackwell. 
Hansford, M. (2008) Contractors File 2008, Top 20 Civil Engineering Contractors, New Civil Engineer, Edited by Mark Hansford, London: Emap Inform

Laryea, S. and Hughes, W. (2006) The price of risk in construction projects, In: Boyd, D (Ed) Procs 22nd Annual ARCOM Conference, 4-6 September 2006, Birmingham, UK, Association of Researchers in Construction Management, 553-561

Liu, M. and Ling, Y.Y. (2005) Modelling a contractor's markup estimation, Journal of Construction Engineering and Management, ASCE, 131(4) 391-399

Mintzberg, H. (1973) The Nature of Managerial Work, New York: Harper and Row

Murdoch, J. and Hughes, W. (2008) Construction contracts, 4ed, London: Taylor \& Francis.

Neufville, R. and King, D. (1991) Risk and need-for-work premiums in contractor bidding, Journal of Construction Engineering and Management, 117(4), 659-73

Rooke, J., Seymour, D. and Fellows, R. (2004) Planning for claims: an ethnography of industry culture, Construction Management and Economics 22(6) 655-662

Shash, A.A. (1998) Bidding practices of sub-contractors in Colorado, Journal of Construction Engineering and Management, ASCE, 124(3), 219-225

Smith, R. C (1986) Estimating and tendering for building work, Longman: London.

Smith, G. R. and Bohn, M. C. (1999) Small to medium contractor contingency and assumption of risk, Journal of Construction Engineering and Management, ASCE, 125(2), 101-108

Snook, K. (1995) CPI - Co-ordinated project information, Chartered Institute of Building, Construction Papers, Number 431995

Wong, J. T. Y. and Hui, E. C. M. (2006) Construction project risks: further considerations for constructors' pricing in Hong Kong, Construction Management and Engineering, 24, 425-438.

Yin, R. K. (2003) Case study research, London: Sage. 


\section{TABLES}

Table 1: Analysis of tender queries (TQ) issued by Gamma

\begin{tabular}{lllllll}
\hline $\begin{array}{l}\text { Query } \\
\text { category }\end{array}$ & Clarification & $\begin{array}{l}\text { Missing } \\
\text { information }\end{array}$ & $\begin{array}{l}\text { Conflicting } \\
\text { information }\end{array}$ & $\begin{array}{l}\text { Inadequate } \\
\text { specifications }\end{array}$ & $\begin{array}{l}\text { Incomplete } \\
\text { drawings }\end{array}$ & Total \\
\hline $\begin{array}{l}\text { Number of } \\
\text { queries }\end{array}$ & 12 & 5 & 1 & 1 & 1 & 20 \\
$\begin{array}{l}\text { Breakdown } \\
- \text { Drawings, }\end{array}$ & $\begin{array}{l}\text { Drawings (1); } \\
\text { Specifications }\end{array}$ & $\begin{array}{l}\text { Drawings (1); } \\
\text { Specifications }\end{array}$ & $\begin{array}{l}\text { Conflict } \\
\text { between info in } \\
\text { specs and info } \\
\text { Specs, BQ }\end{array}$ & $\begin{array}{l}\text { Inadequate } \\
\text { specification for } \\
\text { grade of concrete }\end{array}$ & $\begin{array}{l}\text { Incomplete } \\
\text { details of pad } \\
\text { footings }\end{array}$ & - \\
Percentage & $60 \%$ & $(4)$ & $5 \%$ & $5 \%$ & $5 \%$ & $100 \%$ \\
\hline
\end{tabular}

Table 2: Examination of tender addenda in Gamma

\begin{tabular}{|c|c|c|c|}
\hline Ref. & Description & Date & Category \\
\hline TA1 & Correction / clarification to date of tender submission & $03 / 07$ & Correction \\
\hline TA2 & $\begin{array}{l}\text { Two compact discs }(\mathrm{CD}) \text { issued during client interview containing } \\
\text { new information }\end{array}$ & $24 / 07$ & $\begin{array}{l}\text { Additional drawings and } \\
\text { specifications }\end{array}$ \\
\hline TA3 & Explanation of contents of the CDs issued at client interview & $29 / 07$ & Clarification \\
\hline TA4 & Additional drawing for drainage to clarify construction method & 28/07 & Additional drawings \\
\hline TA5 & $\begin{array}{l}\text { This addendum was issued in two parts. Part I - drawing to clarify } \\
\text { some aspects of the work. Part II - further drawings to clarify the } \\
\text { works and a revision summary for the works }\end{array}$ & $29 / 07$ & Additional drawings \\
\hline TA6 & $\begin{array}{l}\text { Amendments to drainage works. A bill of quantities covering the } \\
\text { revised drainage works is issued for contractors to price. }\end{array}$ & $30 / 07$ & $\begin{array}{l}\text { Additional bill of } \\
\text { quantities }\end{array}$ \\
\hline TA7 & Revision drawing on changes to levels of two roads & $30 / 07$ & Revised drawings \\
\hline TA8 & Extension of tender submission & $31 / 07$ & Notification \\
\hline TA9 & Specification details for some aspects of the work & $05 / 08$ & Additional specifications \\
\hline
\end{tabular}

Note: TA refers to Tender Addendum/Amendment

Table 3: Analysis and categorization of tender query responses in Gamma

\begin{tabular}{lllllllll}
\hline $\begin{array}{l}\text { Query } \\
\text { category }\end{array}$ & Clarification & $\begin{array}{l}\text { Missing } \\
\text { information }\end{array}$ & $\begin{array}{l}\text { Conflicting } \\
\text { information }\end{array}$ & $\begin{array}{l}\text { Inadequate } \\
\text { specifications }\end{array}$ & $\begin{array}{l}\text { Errors and } \\
\text { mistakes }\end{array}$ & Omissions & $\begin{array}{l}\text { Incomplete } \\
\text { drawings }\end{array}$ & $\begin{array}{c}\text { Total } \\
\text { Query }\end{array}$ \\
$\begin{array}{l}\text { responses } \\
\text { Percentage }\end{array}$ & 27 & 2 & 4 & 24 & 5 & 18 & 10 & 90 \\
\hline
\end{tabular}

Table 4: Weekly distribution of tender query responses in Gamma

\begin{tabular}{llllllllll}
\hline $\begin{array}{l}\text { Tender } \\
\text { period }\end{array}$ & Week1 & Week2 & Week3 & Week4 & Week5 & Week6 & $\begin{array}{l}\text { No date } \\
\text { stated }\end{array}$ & $\begin{array}{l}\text { Not } \\
\text { answered }\end{array}$ & Total \\
\hline $\begin{array}{l}\text { Query } \\
\text { responses }\end{array}$ & 0 & 4 & 13 & 12 & 28 & 20 & 9 & 4 & 90 \\
$\begin{array}{l}\text { Percentage } \\
0 \%\end{array}$ & $4 \%$ & $14 \%$ & $13 \%$ & $31 \%$ & $22 \%$ & $10 \%$ & $4 \%$ & $100 \%$ \\
\hline
\end{tabular}


Table 5: Details of tender queries (TQ) issued by Gamma

\begin{tabular}{|c|c|c|c|c|c|}
\hline Ref. & Subject / Description & Sent & Replied & Days & Category \\
\hline TQ01 & One drawing listed in tender documents is not issued. & $08 / 07$ & $15 / 07$ & 5 & Drawing \\
\hline TQ02 & $\begin{array}{l}\text { Existing building on the site needs to be demolished. } \\
\text { Contractor is to design and reconstruct it. However, no } \\
\text { information is provided about details of the pad footings. }\end{array}$ & 08/07 & $22 / 07$ & 10 & $\begin{array}{l}\text { Missing } \\
\text { information }\end{array}$ \\
\hline TQ03 & $\begin{array}{l}\text { Tender documents indicated that Volume } 5 \text { of the } \\
\text { documents will follow later. No date was given. "This is a } \\
\text { polite reminder that it is needed to help in planning and } \\
\text { pricing certain aspects of the work". }\end{array}$ & 08/07 & $17 / 07$ & 7 & $\begin{array}{l}\text { Incomplete } \\
\text { drawings }\end{array}$ \\
\hline TQ04 & Discrepancy between specs and what is stated in drawings. & 08/07 & $15 / 07$ & 5 & $\begin{array}{l}\text { Missing } \\
\text { information }\end{array}$ \\
\hline TQ05 & $\begin{array}{l}\text { Technical query that relates to a concrete road that needs to } \\
\text { be constructed. There is no specification for the grade of } \\
\text { concrete that needs to be placed. }\end{array}$ & 08/07 & $15 / 07$ & 5 & Conflicting info \\
\hline TQ06 & $\begin{array}{l}\text { The construction of a foul drainage is described. However, } \\
\text { the notes are vague. Contractor wants a clarification of the } \\
\text { requirements. }\end{array}$ & $09 / 07$ & $16 / 07$ & 5 & $\begin{array}{l}\text { Inadequate } \\
\text { specifications }\end{array}$ \\
\hline TQ07 & $\begin{array}{l}\text { Request for construction environmental management plan } \\
\text { and construction management plan - Contractor wants it at } \\
\text { tender stage; client has already submitted a copy of these } \\
\text { two documents for approval purposes. }\end{array}$ & $10 / 07$ & $21 / 07$ & 7 & Clarification \\
\hline TQ08 & Clarification for one of the materials specified & $14 / 07$ & $24 / 07$ & 8 & $\begin{array}{l}\text { Missing } \\
\text { information }\end{array}$ \\
\hline TQ09 & 1050 diameter manhole inverts -follow up on Q6 & $16 / 07$ & $22 / 07$ & 4 & Clarification \\
\hline TQ10 & Missing pavement schedule & $22 / 07$ & $28 / 07$ & 4 & Clarification \\
\hline TQ11 & $\begin{array}{l}\text { Contractor wants to know the significance of a sectional } \\
\text { completion date, why it is set; and whether it has a bearing } \\
\text { on other factors apart from an existing access }\end{array}$ & $24 / 07$ & $28 / 07$ & 2 & $\begin{array}{l}\text { Missing } \\
\text { information }\end{array}$ \\
\hline TQ12 & $\begin{array}{l}\text { Contractor wants to know more about the relationship } \\
\text { between a road, whether it is a requirement for early access } \\
\text { to build bridge, and who will be responsible on its handover; } \\
\text { and whether it necessarily will run through the project site. }\end{array}$ & 24/07 & $28 / 07$ & 2 & Clarification \\
\hline TQ13 & $\begin{array}{l}\text { Contractor requires further clarification regarding the extent } \\
\text { and scope of utilities work }\end{array}$ & 24/07 & $25 / 07$ & 1 & Clarification \\
\hline TQ14 & $\begin{array}{l}\text { Contractor wants to know whether list of possible novated } \\
\text { parties are required }\end{array}$ & $24 / 07$ & $25 / 07$ & 1 & Clarification \\
\hline TQ15 & $\begin{array}{l}\text { Contractor wants to know how provisional sums will be } \\
\text { measured on the contract, in order to assess programme } \\
\text { implications, and assess and quantify risk }\end{array}$ & $24 / 07$ & $25 / 07$ & 1 & Clarification \\
\hline TQ16 & $\begin{array}{l}\text { Contractor wants to know whether sites have been allocated } \\
\text { / identified for any trapped species during the contract }\end{array}$ & $24 / 07$ & $25 / 07$ & 1 & Clarification \\
\hline TQ17 & $\begin{array}{l}\text { Contractor wants clarification of requirement for outfalls } \\
\text { against Bill of Quantities }\end{array}$ & $24 / 07$ & $25 / 07$ & 1 & Clarification \\
\hline TQ18 & Follow on action, previous sheet says no action at this point & $07 / 08$ & $12 / 08$ & 3 & Clarification \\
\hline TQ19 & TQ regarding non-issue of sectional completion dates & 08/08 & $12 / 08$ & 2 & Clarification \\
\hline \multirow[t]{2}{*}{ TQ20 } & TQ regarding possession dates. & $08 / 08$ & $11 / 08$ & 1 & $\begin{array}{l}\text { Missing } \\
\text { information }\end{array}$ \\
\hline & & & AVG & 4 & \\
\hline
\end{tabular}

\begin{tabular}{llllll}
\hline \multicolumn{2}{l}{ Table $6:$ Analysis (and details) of tender queries (TQ) issued by Delta } & & \\
\hline Ref. & Subject / Description & Sent & Replied & Days & Category \\
\hline EM01 & Initial thoughts on the scheme, tender appraisal, and & $19 / 08$ & - & - & - \\
\end{tabular}




\begin{tabular}{|c|c|c|c|c|c|}
\hline & preliminary risk assessment & & & & \\
\hline EM02 & Request for MS WORD version of PDF documents & $15 / 09$ & $19 / 09$ & 2 & - \\
\hline EM03 & $\begin{array}{l}\text { Clarification of vehicular access points discussed for use as } \\
\text { access, material delivery, and possible location for port cabins } \\
\text { for site personnel. }\end{array}$ & $19 / 09$ & - & $\begin{array}{l}\text { No } \\
\text { response }\end{array}$ & Clarification \\
\hline TQ01 & $\begin{array}{l}\text { Can you please confirm the Pile Loading on the proposed } \\
\text { raking piles for the extension of platform one. The current } \\
\text { design shown on drawing [drawing no. stated] is not feasible } \\
\text { for installation and are looking at an alternative design }\end{array}$ & $24 / 09$ & - & $\begin{array}{l}\text { No } \\
\text { response }\end{array}$ & $\begin{array}{l}\text { Missing } \\
\text { information }\end{array}$ \\
\hline \multicolumn{6}{|c|}{ Note: EM refers to email, and $T Q$ refers to tender query. } \\
\hline
\end{tabular}

Table 7: Analysis and categorization of tender query responses in Delta

\begin{tabular}{|c|c|c|c|c|c|c|c|}
\hline $\begin{array}{l}\text { Query } \\
\text { category }\end{array}$ & Clarification & $\begin{array}{l}\text { Missing } \\
\text { information }\end{array}$ & $\begin{array}{l}\text { Conflicting } \\
\text { information }\end{array}$ & $\begin{array}{l}\text { Inadequate } \\
\text { specifications }\end{array}$ & $\begin{array}{l}\text { Errors and } \\
\text { mistakes }\end{array}$ & $\begin{array}{l}\text { Software } \\
\text { difficulties }\end{array}$ & Total \\
\hline $\begin{array}{l}\text { Query } \\
\text { responses }\end{array}$ & 4 & 5 & 1 & 8 & 2 & 3 & 23 \\
\hline $\begin{array}{l}\text { Breakdown } \\
\text { - Drawings, } \\
\text { Specs, ITT, } \\
\text { BQ }\end{array}$ & $\begin{array}{l}\text { ITT (2); } \\
\text { Specs (1); } \\
\text { Drawings (1) }\end{array}$ & $\begin{array}{l}\text { Drawings } \\
\text { (2); ITT } \\
\text { (3) }\end{array}$ & ITT (1) & $\begin{array}{l}\text { Eight TQs } \\
\text { relating to } \\
\text { materials }\end{array}$ & $\begin{array}{l}\text { ITT (1); BQ } \\
\text { (1) }\end{array}$ & $\begin{array}{l}\text { Drawings } \\
\text { (3) }\end{array}$ & - \\
\hline Percentage & $17 \%$ & $22 \%$ & $4 \%$ & $35 \%$ & $9 \%$ & $13 \%$ & $100 \%$ \\
\hline
\end{tabular}

Table 8: Weekly distribution of tender query responses in Delta

\begin{tabular}{lllllllll}
\hline $\begin{array}{l}\text { Tender } \\
\text { period }\end{array}$ & Week1 & Week2 & Week3 & Week4 & Week5 & Week6 & Week7 & Total \\
\hline $\begin{array}{l}\text { Number of } \\
\text { queries }\end{array}$ & 0 & 0 & 0 & 20 & 0 & 2 & 1 & 23 \\
Percentage & $0 \%$ & $0 \%$ & $0 \%$ & $87 \%$ & $0 \%$ & $9 \%$ & $4 \%$ & $100 \%$ \\
\hline
\end{tabular}

Table 9: Examination of tender addenda (TA) in Delta

\begin{tabular}{llll}
\hline Ref. & Subject / Description & Date & Category \\
\hline TA1 & $\begin{array}{l}\text { CD containing Tender Amendment No. 1 - Technical Work scope for the } \\
\text { [Project], with section 3.4 OLE works added to the remit, as well as } \\
\text { relevant drawings required. There is also a list of technical items that } \\
\text { should be submitted by the Tenderer. }\end{array}$ & $03 / 07$ & $\begin{array}{l}\text { Additional } \\
\text { information }\end{array}$ \\
TA2 & $\begin{array}{l}\text { All works relating to [x] foundations taken out of the scope of main } \\
\text { contractor's work but contractor is responsible for the works }\end{array}$ & $06 / 10$ & $\begin{array}{l}\text { Amendment to } \\
\text { works scope }\end{array}$ \\
Note: TA refers to Tender Addendum/Amendment &
\end{tabular}

